\title{
Glycine Amidinotransferase, Mitochondrial
}

National Cancer Institute

\section{Source}

National Cancer Institute. Glycine Amidinotransferase, Mitochondrial. NCI Thesaurus.

Code C122898.

Glycine amidinotransferase, mitochondrial ( $423 \mathrm{aa}, \sim 48 \mathrm{kDa}$ ) is encoded by the human GATM gene. This protein plays a role in the conversion of L-arginine and glycine to creatine. 